\title{
MAJOR-ELEMENT OXIDE, TRACE ELEMENT, AND GLASS COMPOSITIONAL ANALYSES FROM HOLOCENETO HISTORICAL ERUPTIONS FROM PAVLOF VOLCANO, ALASKA
}

Jessica F. Larsen, Christopher F. Waythomas, Katherine M. Mulliken, Pavel Izbekov, and Cheryl E. Cameron

Preliminary Interpretive Report 2021-1

This publication is PRELIMINARY in nature and meant to allow rapid release of field observations or initial interpretations of geology or analytical data. It has undergone limited peer review, but does not necessarily conform to DGGS editorial standards. Interpretations or conclusions contained in this publication are subject to change.

2021

STATE OF ALASKA

DEPARTMENT OF NATURAL RESOURCES

DIVISION OF GEOLOGICAL \& GEOPHYSICAL SURVEYS
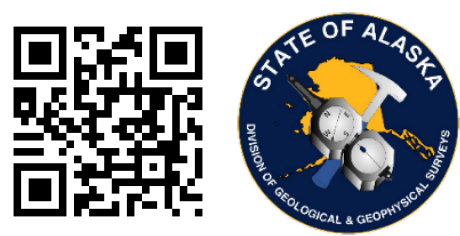
STATE OF ALASKA

Mike Dunleavy, Governor

\title{
DEPARTMENT OF NATURAL RESOURCES
}

Corri A. Feige, Commissioner

\section{DIVISION OF GEOLOGICAL \& GEOPHYSICAL SURVEYS}

Steve Masterman, State Geologist \& Director

Publications produced by the Division of Geological \& Geophysical Surveys are available to download from the DGGS website (dggs.alaska.gov). Publications on hard-copy or digital media can be examined or purchased in the Fairbanks office:

\author{
Alaska Division of Geological \& Geophysical Surveys (DGGS) \\ 3354 College Road | Fairbanks, Alaska 99709-3707 \\ Phone: 907.451 .5010 | Fax 907.451.5050 \\ dggspubs@alaska.gov $\mid$ dggs.alaska.gov
}

DGGS publications are also available at:

Alaska State Library, Historical

Collections \& Talking Book Center

395 Whittier Street

Juneau, Alaska 99801

Alaska Resource Library and

Information Services (ARLIS)

3150 C Street, Suite 100

Anchorage, Alaska 99503

\section{Suggested citation:}

Larsen, J.F., Waythomas, C.F., Mulliken, K.M., Izbekov, Pavel, and Cameron, C.E., 2021, Major-element oxide, trace element, and glass compositional analyses from Holocene to historical eruptions from Pavlof Volcano, Alaska: Alaska Division of Geological \& Geophysical Surveys Preliminary Interpretive Report 2021-1, 20 p. https://doi.org/10.14509/30580

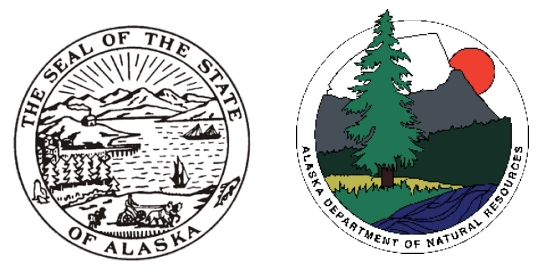




\section{MAJOR-ELEMENT OXIDE, TRACE ELEMENT, AND GLASS COMPOSITIONAL ANALYSES FROM HOLOCENE TO HISTORICAL ERUPTIONS FROM PAVLOF VOLCANO, ALASKA}

Jessica F. Larsen ${ }^{1}$, Christopher F. Waythomas², Katherine M. Mulliken³, Pavel Izbekov', and CherylE. Cameron $^{3}$

\section{INTRODUCTION}

During the summers of 2017 and 2018, Alaska Volcano Observatory (AVO) geologists from the University of Alaska, Fairbanks (UAF), the U.S. Geological Survey (USGS), and the Alaska Division of Geological \& Geophysical Surveys (DGGS) conducted fieldwork at Pavlof Volcano (55.4173 N, -161.8937 W), on the Alaska Peninsula, Alaska (fig. 1). The fieldwork was conducted in support of geologic mapping and tephrostratigraphy, to improve the documentation of recent Pavlof eruptions, and to better assess hazards associated with Pavlof eruptions. As a result, samples of lava and various pyroclasts (mainly bombs and lapilli) were collected for whole rock geochemistry analyses (table A1). This report includes whole rock major- and trace-element data from lava and bomb samples from the 1996, 2013, 2014, and 2016 eruptions, along with samples of lava and lapilli fall deposits, presumed to be of Holocene age, collected from outcrops around Pavlof and Pavlof Sister volcanoes (this data provided in table $\mathrm{Al}$ and in the accompanying data tables available to download at (http://doi.org/10.14509/30580). We also include electron probe microanalyzer (EPMA) data from tephra glass samples from the 1986 (AT-2822), 1996 (AT-2823), 2007 (AT-2824), and 2013 (AT-2821) eruptions. These samples were initially analyzed at the USGS office in Menlo Park (Waythomas and others, 2017) and were reanalyzed for this report in the Advanced Instrumentation Laboratory (AIL) at UAF for comparison. Tephra EPMA glass data from the 2016 eruption, analyzed in the AIL, is also included from sample AT-3680.

\section{GEOLOGICAL SETTING}

Pavlof Volcano is located in the southwestern region of the Alaska Peninsula to the east of the Izembek National Wildlife Refuge (fig. 1). The volcano is $58 \mathrm{~km}$ northeast of Cold Bay, $48 \mathrm{~km}$ northeast of King Cove, and $950 \mathrm{~km}$ southeast of Anchorage. Pavlof is one of the most frequently active volcanoes in the United States, producing at least 45 eruptions since 1790 (Miller and others, 1998; Waythomas and others, 2017). Located on the northeast margin of Emmons Lake caldera, Pavlof is a $\sim-\mathrm{km}$-diameter undissected stratovolcano (McNutt and others, 1991; Miller and others, 1998) with a summit altitude of $2518 \mathrm{~m}$ and about $2000 \mathrm{~m}$ of relief. Pavlof s most recent activity, in October of 2019, was characterized by small explosions indicated in infrasound data, as well as elevated summit surface temperatures; however, weather obscured eyewitness and satellite views of the activity. A second stratovolcano, Pavlof Sister, lies $5 \mathrm{~km}$ to the northeast and likely has not erupted during historical times. Pavlof (and Pavlof Sister) produces predominantly basaltic andesite magmas that have relatively uniform compositions (Miller and others, 1998; Mangan and others, 2009).

\footnotetext{
${ }^{1}$ University of Alaska Fairbanks, Department of Geosciences, P.O. Box 755790, Fairbanks, AK 99775; jllarsen@alaska.edu

${ }^{2}$ U.S. Geological Survey Alaska Volcano Observatory, 4230 University Drive, Suite 100, Anchorage, Alaska 99508

${ }^{3}$ Alaska Division of Geological \& Geophysical Surveys, 3354 College Road, Fairbanks, AK 99709; Katherine Mulliken now at U.S. Geological SurveyHawaiian Volcano Observatory
} 


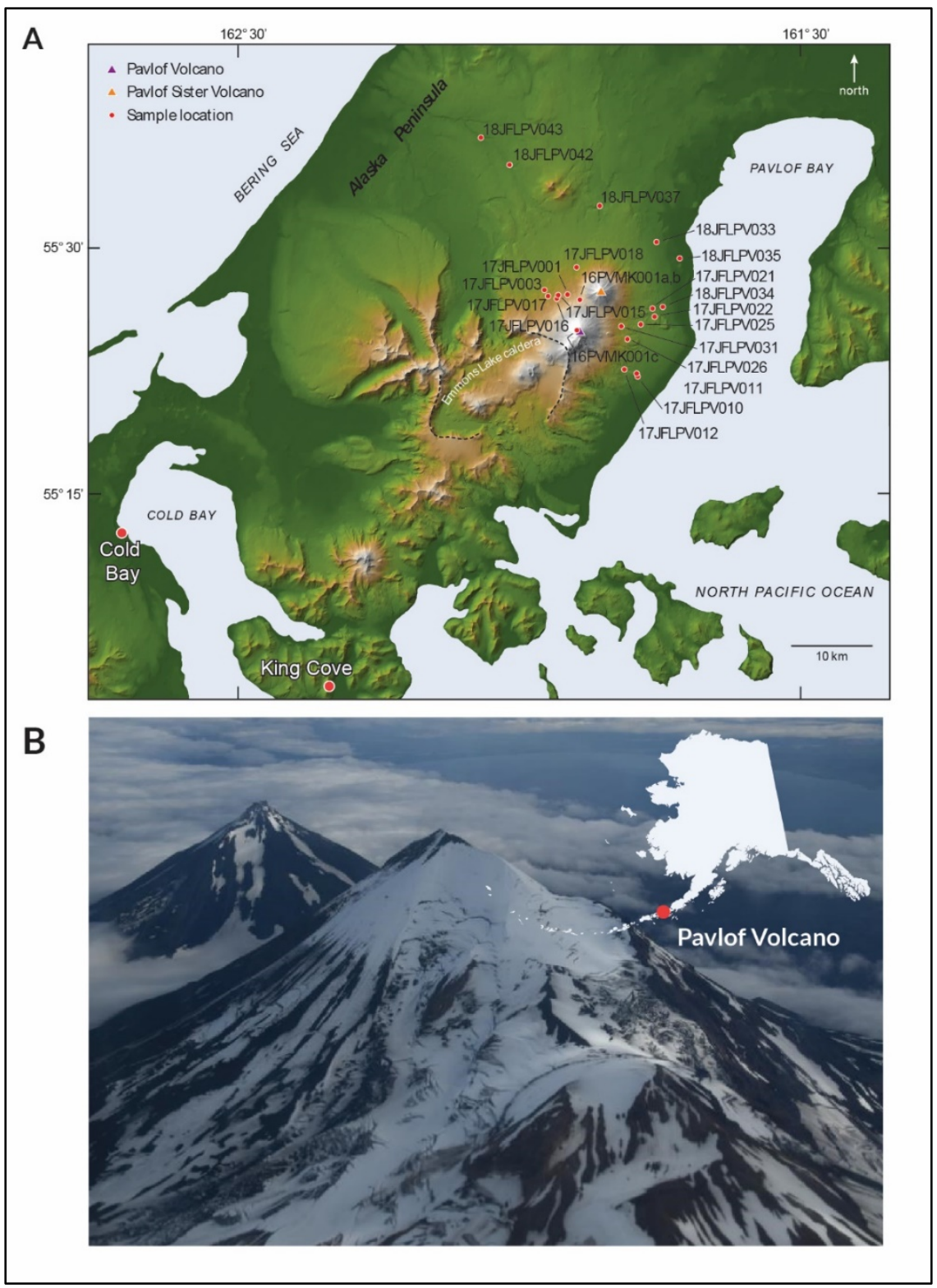

Figure 1. A. Map figure showing the location of Pavlof Volcano in Alaska, and the locations of the outcrop stations and samples included in this report. Nelson Lagoon is located off the map to the north east of Pavlof. B. Oblique aerial photograph of Pavlof Volcano in the foreground, with Pavlof Sister volcano in the background. Oblique aerial photograph by Janet Schaefer, Alaska Volcano Observatory/Alaska Division of Geological \& Geophysical Surveys.

\section{PRE-HISTORIC, HOLOCENE, AND PLEISTOCENE SAMPLES AND GEOCHEMISTRY}

Eight lava samples from lava flows of unknown but presumed Holocene age were collected for geochemical analysis (figs. 1 and 2, appendix A). The lava flows exhibit no evidence of being glaciated and in some locations overlie glacial deposits of late Pleistocene-Holocene age. These lava flows are basaltic to basaltic andesite in composition (fig. 2), except for 17JFLPV022, which is an ice-contact lava flow with high silica andesite composition (fig. 3B). Eleven whole rock geochemical analyses were obtained on samples 
collected from tephra fall deposits of Holocene age obtained from stratigraphic profiles on the northeast to southeast distal flanks of Pavlof Sister (figs. 1 and 3A, appendix A). These tephra fall samples are all basaltic andesite in composition. All Holocene lava flow and tephra fall analyses, except for 17JFLPV022, are consistent with the Pavlof compositional trend described by Mangan and others (2009), and are slightly enriched in oxides such as the alkalis $\left(\mathrm{Na}_{2} \mathrm{O}+\mathrm{K}_{2} \mathrm{O}\right)$ and a subset of rare earth elements $(\mathrm{La})$ when compared with Pavlof Sister data from a prior study (Mangan and others, 2009). However, we note that substantial overlap between the Pavlof and Pavlof Sister geochemical data precludes interpretations about similarities or differences in their magmatic source regions (Mangan and others, 2009). Sample 17JFLPV021A was collected from a lava flow of ambiguous provenance. While its composition is more consistent with the Pavlof trend (fig. 2), the location suggests that it could have been erupted by Pavlof Sister. Previous studies have demonstrated that despite their geographical proximity, Pavlof and Pavlof Sister stratovolcanoes appear to have tapped spatial and/or temporally separated magmatic sources in the lower crust (Mangan and others, 2009). Analyses reported here support this interpretation.

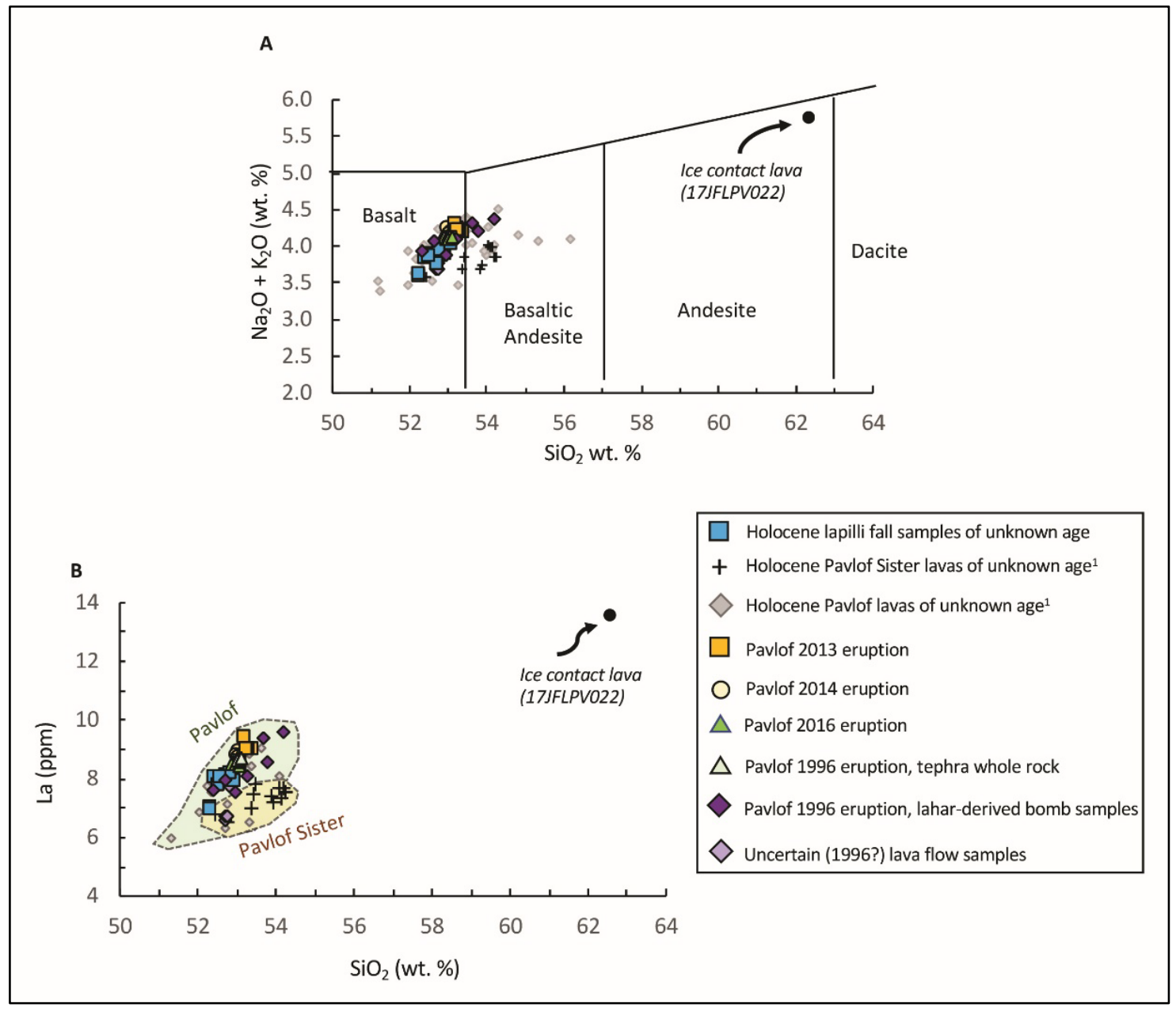

Figure 2. Whole rock geochemistry data published in this report, along with comparison data from Mangan et al. (2009) for the Holocene Pavlof and Pavlof Sister lavas of unknown age ('gray diamond and plus symbols). A. Total alkali versus silica diagram (Le Bas and others, 1986), showing the majority of the magmas erupted from Pavlof volcano are basaltic andesite in composition. B. Rare earth element $\mathrm{La}(\mathrm{ppm})$ plotted versus $\mathrm{SiO}_{2}(\mathrm{wt} . \%)$. The purpose of this plot is to show the subtle but significant difference in the magma compositions from Pavlof versus Pavlof Sister volcano. 


\section{HISTORICAL ERUPTION SAMPLES AND GEOCHEMISTRY}

A total of 29 geochemical analyses have been collected from lava flow and bomb samples from the 1996, 2013, 2014, and 2016 eruptions. The samples were tied to specific eruptions on the basis of satellite imagery and mapping conducted by Christopher Waythomas before and during the 2017 and 2018 field seasons. Geochemical analyses from the 2013, 2014, and 2016 deposits show consistent compositional groupings, with the exception of 17JFLPV001A and 17JFLPV01B, which were originally attributed to Pavlof s 2016 eruption, but have since been re-interpreted to belong to the 2013 eruption on the basis of their compositional similarity with the rest of the 2013 data (fig. 2).

Lava flows exposed to the northwest of Pavlof Sister (17JFLPV018; figs. 1 and 3, appendix A) were collected because they have been identified as possibly representing the Pavlof 1996 eruption. The samples were collected in a region where lavas from either volcano could have been deposited, leaving a question about whether the samples collected there came from Pavlof or Pavlof Sister. Of those four samples, 17JFLPV018C, 17JFLPV018B, and 17JFLPV018D have lower La versus $\mathrm{SiO}_{2}$ when compared with the tephra whole rock data from confirmed 1996 samples, from bombs collected from the 1996 lahar deposits in the Leontovich River valley, and with the samples from the 2013,2014, and 2016 Pavlof eruptions (fig. 2; Mangan and others, 2009). It is possible that those lava flows may have emanated from Pavlof Sister rather than Pavlof, although the geochemical similarities between Pavlof and Pavlof Sister from all Holocene data make this interpretation inconclusive. It is also possible that those samples could also be from older, Holocene Pavlof lavas rather than Pavlof Sister . However, sample 17JFLPV018A is consistent with other 1996 analyses and could represent a smaller area of 1996 lavas exposed in this location. Additional samples of the 1996 eruption were collected from bombs found in 1996 lahar deposits in the Leontovitch River valley to the north of the volcano (figs. 1 and 4). It is difficult to completely verify the provenance of bomb samples collected from flowage deposits. However, care was taken when sampling bombs from the 1996 lahar deposits and only fresh-looking bombs that displayed evidence of hot deposition (jigsaw fractures, spalling, little surface weathering) were selected. The spread in composition of the 1996 samples indicates that the 1996 eruption may have produced a broader spectrum of magma compositions than the 2013, 2014, or 2016 eruptions. Alternatively, the lahar bomb samples could represent bombs from different eruptions, including 1996, that were swept downstream from deposits higher on the flanks of the volcano by the lahars.

The 2013, 2014, and 2016 eruptions produced clastogenic lava flows, pyroclastic flows, and lahars that traveled predominantly to the north and northwest and are found within $10 \mathrm{~km}$ of the summit (figs. 1 and 4). Samples collected from those deposits consist of juvenile bombs up to $\sim 1$ meter in size that were sampled from the surfaces of the clastogenic deposits or pyroclastic flow deposits or from the dense interiors of the lava flows (fig. 4).

Samples from the 2013 eruption (fig. 1, appendix A) were collected by reference to mapping based on satellite imagery, and were tied to new deposits recognized during this event (Waythomas and others, 2014). Four samples were collected from deposits identified as 2013, with two additional samples re-interpreted as 2013 (17JFLPV001A, 001B; fig. 1, appendix A). The 2014 eruption produced similar clastogenic lava flow and pyroclastic flow deposits, and 5 samples were collected. Similarly, the 2016 eruption produced clastogenic lava flows and pyroclastic flows that followed a similar depositional pattern to the 2013 and 2014 deposits and 7 
samples were collected and analyzed from three different locations (17JFLPV003; 17JFLPV015; 17JFLPV017; fig. 1, appendix A).

The 1996, 2013, 2014, and 2016 eruptions produced basaltic andesite magmas that are consistent with the rest of the Holocene Pavlof geochemical trends (fig. 2; Mangan and others, 2009). However, subtle distinctions exist in certain elements (fig. 2). The 2013 eruption samples are slightly more $\mathrm{SiO}_{2}$-and La-rich than the 2014 and 2016 samples. This indicates that while the source magmatic processes likely remain largely unchanged throughout the Holocene (Mangan and others, 2009), individual eruptions tap magmas that experienced different crystallization histories in the crustal magma plumbing system, and that those changes can take place during short repose timescales (e.g., between 2013 and 2016). The 1996 lavas show a much broader range in $\mathrm{SiO}_{2}$, from 52.4 to $54.2 \mathrm{wt}$. $\% \mathrm{SiO}_{2}$, than the more tightly grouped 2013, 2014, and 2016 samples. The samples were collected from lahar deposits because we did not identify in-situ 1996 lava flows or pyroclastic flows because they are buried by later
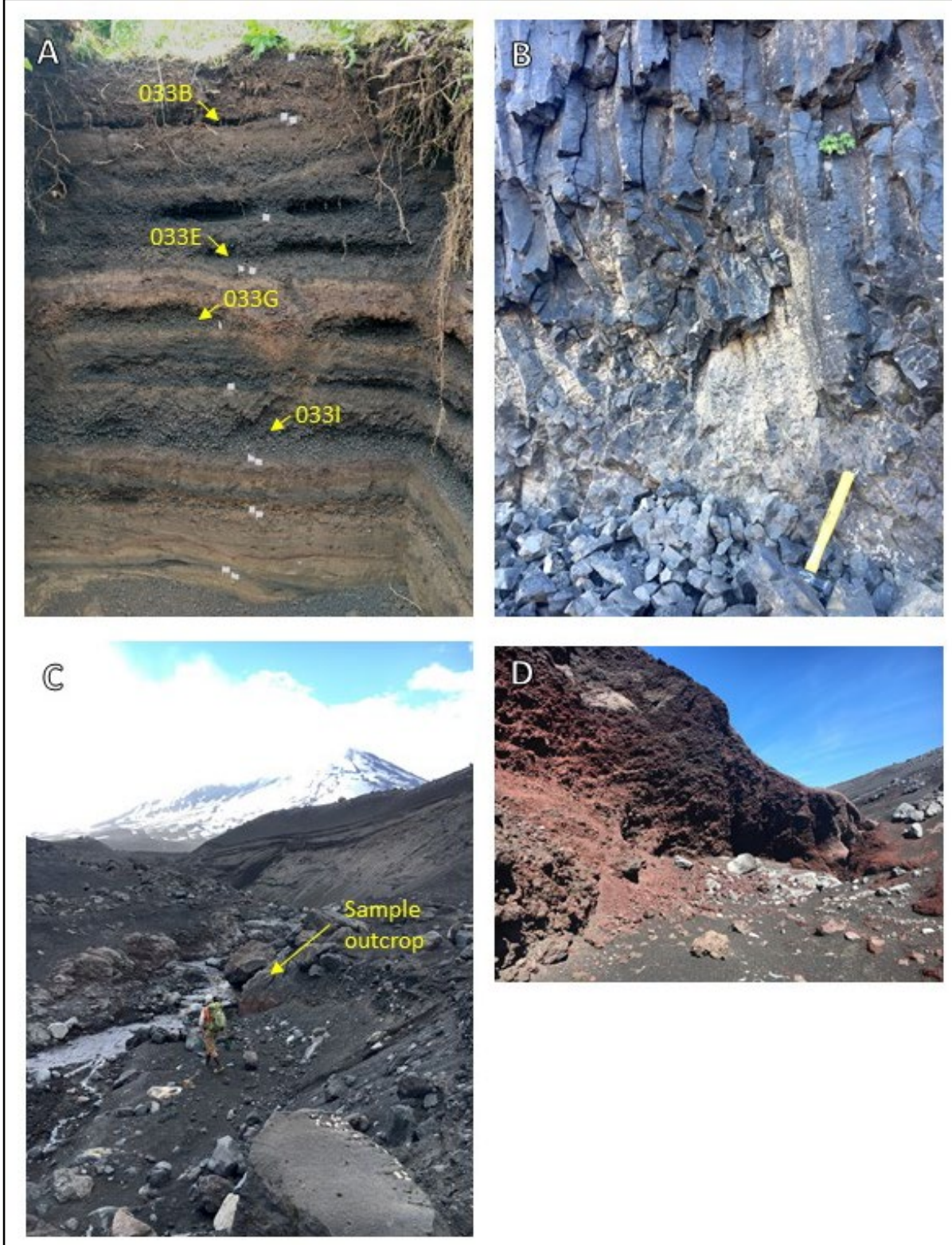

eruptions. It is difficult to say whether the 1996 bomb samples are all representative of the same eruption or magma.

Figure 3. Representative outcrop and sample location photos for Holocene Pavlof analyses included in this report.

A. Station 18JFLPV033 showing the tephra layers sampled for geochemistry: 18JFLPV033B; 18JFLPV033E, 18JFLPV033G, 18JFLPV033I. B. 17JFLPV022 sample from a hackly fractured, micro-columnar jointed, glassy, ice-contact lava flow. C. Holocene lava flow of unknown age (17JFLPV026) covered with younger tephra and soil layers. D. Red oxidized and rubbly lava flow of unknown age outcropping to the north of Pavlof and Pavlof Sister. The lava flow age and stratigraphy here is not well-defined, and the source is ambiguous and could be Pavlof or Pavlof Sister. 


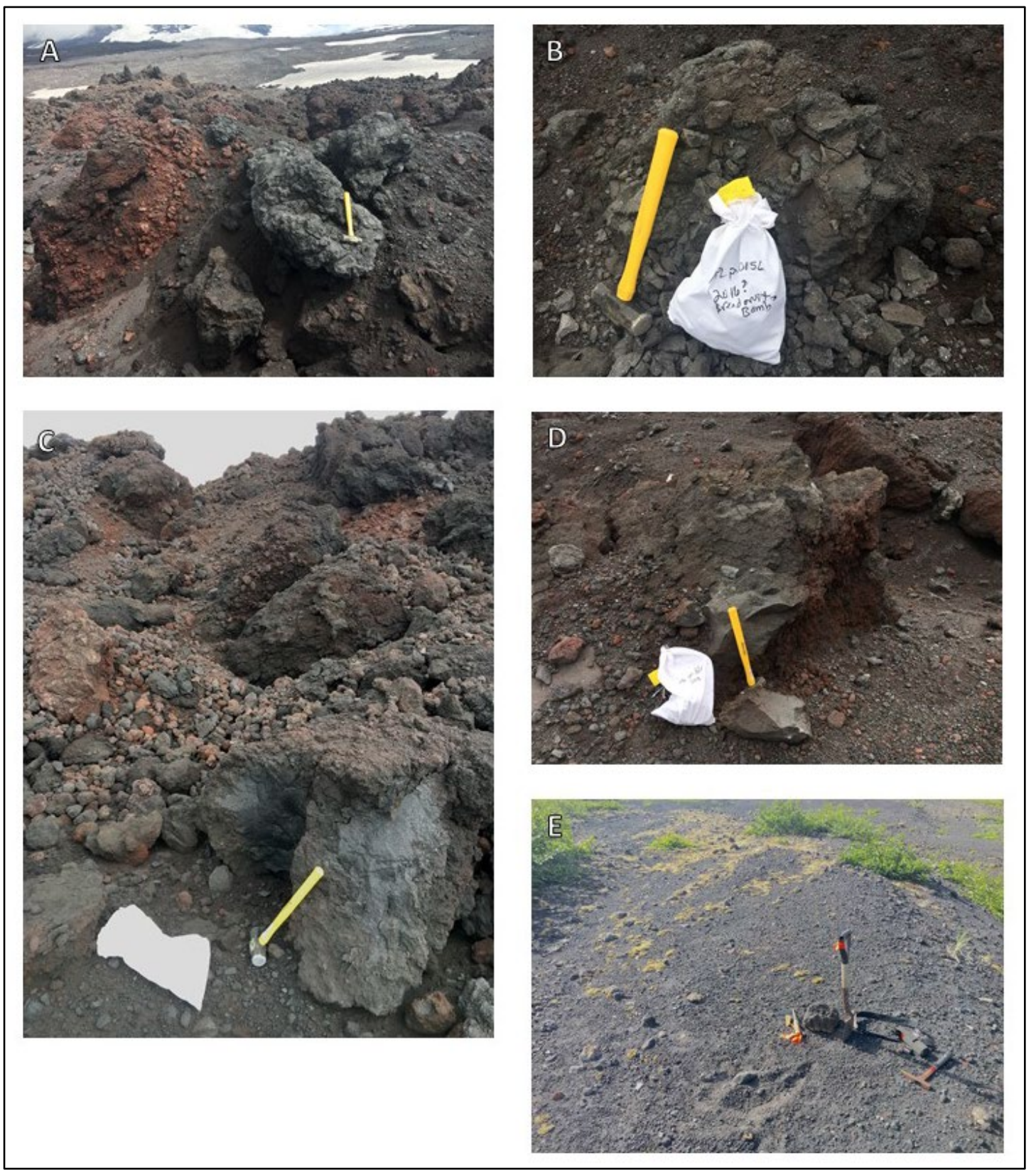

Figure 4. Representative outcrop photos and sample location photos for recent Pavlof eruptions. A. This photograph shows large bombs (>1 meter, hammer for scale) from 2016 pyroclastic flow deposits mantling a lava flow from the 2014 eruption. B. Sample location 17JFLPV015C showing bomb sample collected from the 2016 pyroclastic flow deposits. C. Location of the 2014 lava flow sample 17JFLPV016A. D. Location of the 2013 lava flow sample 17JFLPV015F. E. Location of fresh looking bomb samples from the 1996 lahar deposits in the Leontovich River valley.

\section{TEPHRA GLASS RE-ANALYSES FOR COMPARISON WITH PRIOR WORK}

AVO has recently developed an EPMA glass analytical routine that is meant to be standardized across different analytical facilities. To test this routine and the resulting analytical data, we utilized the UAF analytical instrumentation to re-analyze a series of Pavlof tephra samples that were originally analyzed at USGS 
analytical facilities in Menlo Park and published in a prior study (Waythomas and others, 2017). The EPMA data included in this report are all normalized to 100 percent, with original totals given (appendix B). The reanalysis data allow us to examine how comparable the analyses are from two different instruments using different analytical routines. Most of the compositions of the major oxides are consistent between the two datasets within 1 sigma standard deviation, relative to the averages. The analyses from AT-2821 (2013 eruption), AT-2822 (1986 eruption), AT-2823 (1996 eruption), and AT-2824 (2007 eruption) overlap completely in $\mathrm{K}_{2} \mathrm{O}$ versus $\mathrm{SiO}_{2}$ (fig. 5). The glass compositions from the 2016 eruption tephras show a slight decrease in $\mathrm{SiO}_{2}$ relative to the 1986, 1996, 2007, and 2013 analyses. The individual 2016 tephra glass analyses range from $\sim 56.5 \mathrm{wt}$. \% to $58 \mathrm{wt}$. \% $\mathrm{SiO}_{2}$, relative to the other tephras which extend from $\sim 57.0$ to $59.5 \mathrm{wt}$. \% (fig. 5). While it is possible that the different analytical routine used for the 2016 tephras may explain this pattern, we note that there is an approximate decreasing trend in $\mathrm{K}_{2} \mathrm{O}$ in the 2016 glasses as well. The whole rock analyses from 2016 are also slightly lower in $\mathrm{SiO}_{2}$ and alkalis in comparison with the 2014 and 2013 eruption samples (fig. 2). Thus, it is also possible that the 2016 eruption represented a slightly more mafic magma, consistent with recharge occurring in between the 2014 and 2016 eruptions.

\section{DOCUMENTATION OF METHODS}

Rock samples consisting of dense lava flow interiors, juvenile bombs, and coarse lapilli tephra were collected over two field seasons for whole rock geochemical analyses in support of a geologic map that is currently in preparation by Christopher Waythomas and to characterize very recent eruptions (2013 and 2016 primarily; also see Waythomas and others, 2017). Dense lava flow and juvenile bomb samples were collected using a sledge hammer, and where possible the samples were chipped in the field to select clean interior regions of the samples for analysis. Some of the flows and bombs were too hard to efficiently chip in the field, and were chipped in the lab after fieldwork was finished. Juvenile samples from the coarse lapilli tephra fall deposits were prepared in the lab after fieldwork was completed. Sample location data were collected using the WGS84 datum using a handheld GPS device and recorded in a field notebook at the outcrop, along with documentation of the units sampled, hand sample descriptions, and stratigraphic information. Station and sample metadata were loaded into AVO's Geologic Database of Information on Volcanoes of Alaska (GeoDIVA) and all locations have been converted to NAD83 as reported in appendix A.

\section{SAMPLE PREPARATION AND ANALYSIS METHODS}

Post-fieldwork lava flow and bomb sample preparation involved chipping all samples that were not cleaned in the field, to select clean interior chips and to remove surface weathering rinds and alteration. The rock chips were cleaned in de-ionized water in an ultrasonic bath and then dried at $60^{\circ} \mathrm{C}$ for at least 48 hours before sealing into pristine plastic sample bags for shipping to the analytical laboratory. The coarse lapilli fall samples were selected for size and only clasts larger than 1 to $2 \mathrm{~cm}$ in diameter were sent for analyses. Whole lapilli clasts were cleaned using de-ionized water in an ultrasonic bath multiple times for each sample with each cleaning session lasting at least 8 hours. In between each ultrasonic bath, the samples were rinsed in 


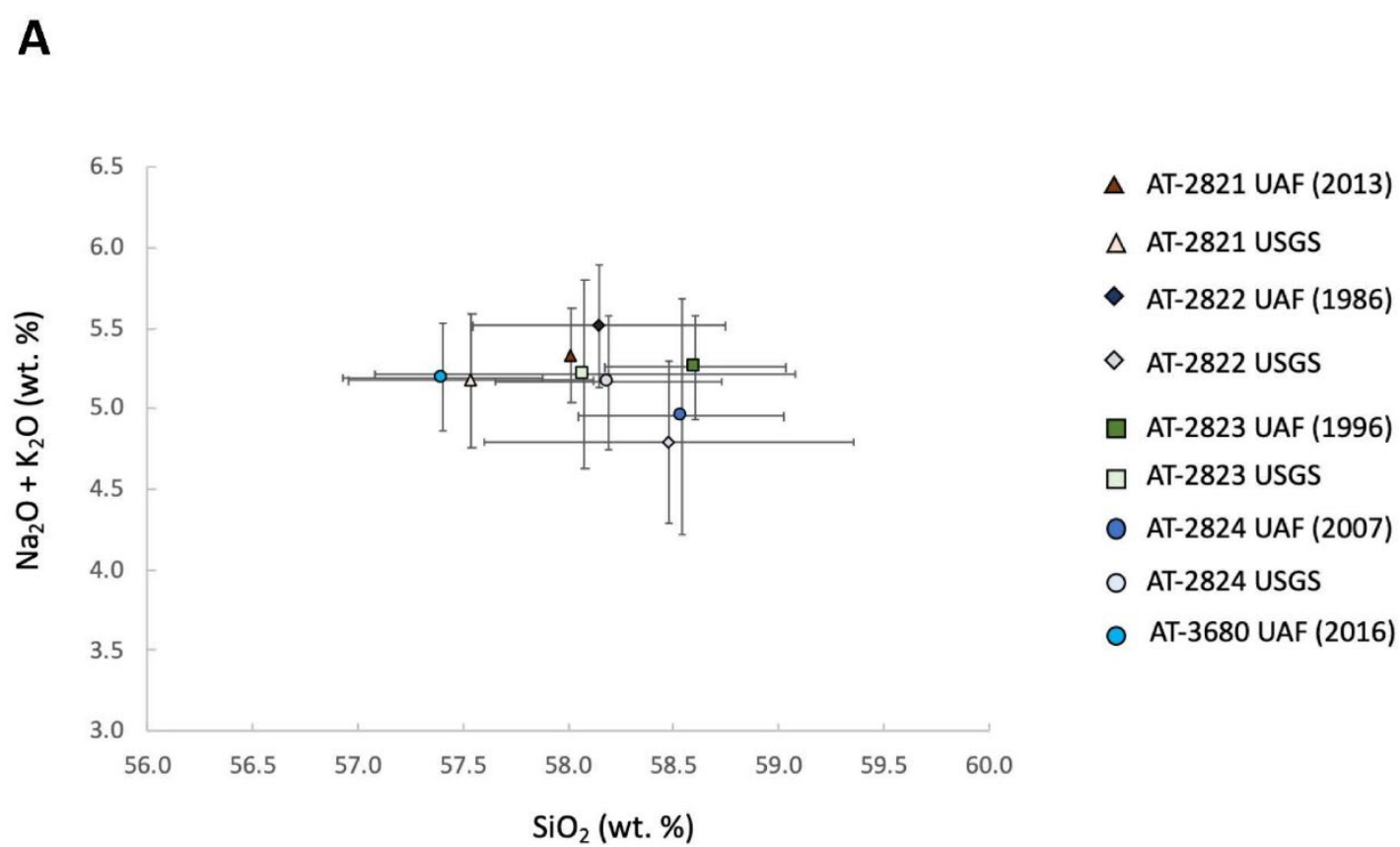

B

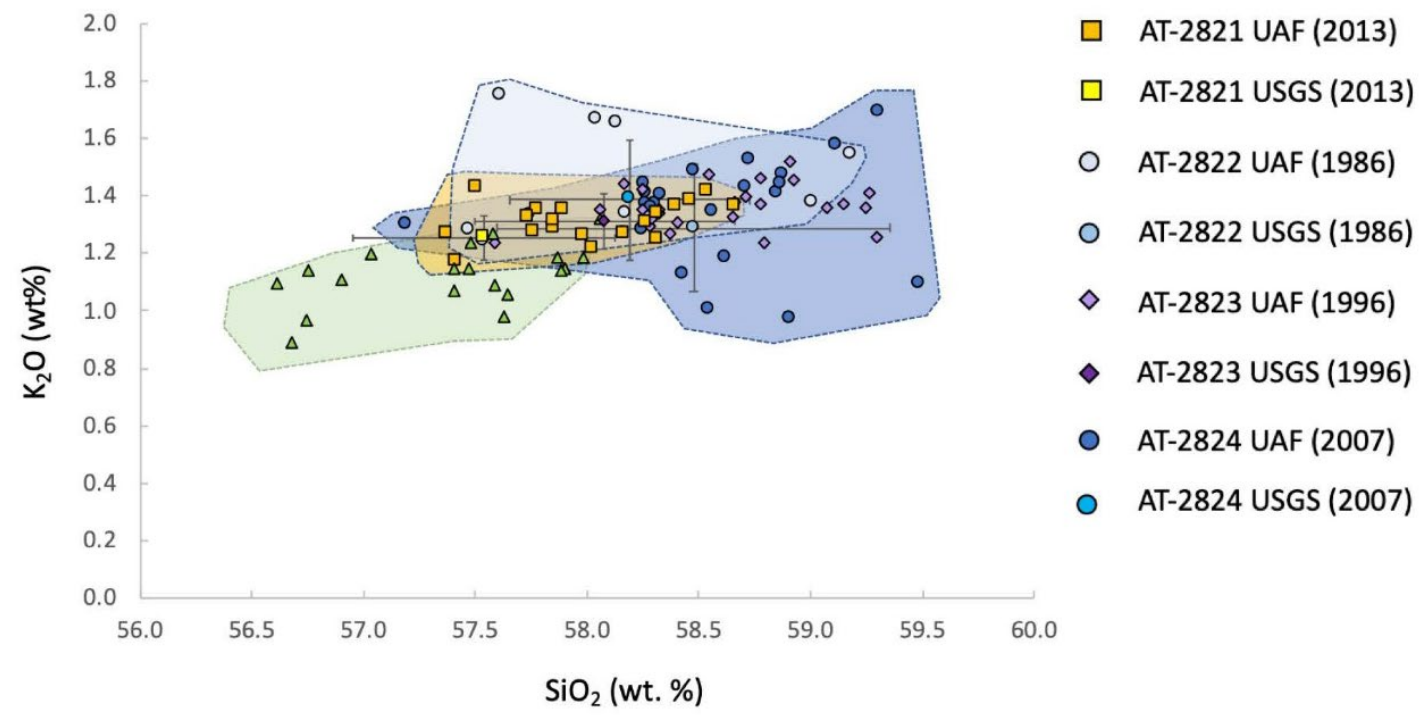

Figure 5. Glass compositional analyses showing the comparison between analyses collected at UAF and those published in Waythomas and others (2017), and new analyses from the 2016 eruption from sample AT-3680. Panel A- $\mathrm{Na}_{2} \mathrm{O}+\mathrm{K}_{2} \mathrm{O}$ versus $\mathrm{SiO}_{2}$ showing the average and standard deviations from all analytical points from the UAF and USGS datasets. All data are statistically similar within $1 \sigma$ standard deviation. Panel $\mathrm{B}-\mathrm{K}_{2} \mathrm{O}\left(\mathrm{wt}\right.$. \%) plotted versus $\mathrm{SiO}_{2}(\mathrm{wt}$. \%) from each UAF analytical point in comparison with the average and standard deviations from the data published in Waythomas and others, (2017). The data overlap within error. The 2016 glass compositions are slightly lower in $\mathrm{SiO}_{2}$ than the other recent eruption glass compositions. 
de-ionized water and the ultrasonic bath water was changed with fresh water added. The cleaned lapilli were then dried at $60^{\circ} \mathrm{C}$ for at least 48 hours prior to sealing in pristine plastic bags for shipping.

The Peter Hooper Geoanalytical Lab at Washington State University (WSU) conducted all whole-rock major- and trace-element analyses published in this report. WSU uses the methods described in Johnson and others (1999) and Knaack and others (WSU, written commun., 1994) for X-ray fluorescence (XRF) and Inductively-Coupled-Plasma Mass Spectrometry (ICP-MS) analyses respectively. Nye and others (2018) provides a detailed description of the analytical protocols applied to these samples, and in that report is an overview of the analytical precision and accuracy and significant digits applicable to this dataset. Comparison with prior analyses published by Mangan and others (2009) is possible because all AVO geochemical analyses were re-calibrated in 2007 so that they are time-consistent and internally consistent with data collected post2007 (Nye and others, 2018).

Tephra samples used for glass analyses consist of two different prepared glass grain mounts. Grain mounts consisting of 1-inch round disks and glass slides were provided by Kristi Wallace (USGS/AVO) for re-analysis by Jessica Larsen in March 2020, after publication in prior study (Waythomas and others, 2017) from the 1986, 1996, 2007, and 2013 eruptions. A second grain mount on a glass slide with tephra from the 2016 eruption was analyzed during a different session in April 2016 by Pavel Izbekov. The analyses from both sets of grain mounts were conducted using the UAF AIL JEOL JXA-8530F electron microprobe. During both sessions, working standards were monitored to track beam and spectrometer drift. Analyses reported are normalized to $100 \%$ "volatile-free" with original totals. We did not correct the analyses to a working standard, as spectrometer drift was negligible. All raw data statistics, analytical precision, and other metadata are included in the AVO tephra database.

During the March 2020 session, the analytical beam was set to $15 \mathrm{keV}$ and $5 \mathrm{nA}$, with a 5 micron beam size. The beam size was set to be broader than a focused beam to mitigate the effects of $\mathrm{Na}, \mathrm{Al}$, and Si migration, yet small enough to fit in the glass pools between crystals in the fairly microlitic tephra shards. A timedependent intensity correction was applied to mitigate Na-loss, with $\mathrm{Na}$ analyzed first in each data point. Calibration standards used for each element from the March 2020 session are: Na - TALBITE; Mg - Diopside (USNM 117733); Al - Corundum; Si - Wollastonite; K - OR10 CT; Ca - Wollastonite; Ti - Rutile; P Apatite; Cl - Scapolite (USNM R6600-1); Fe- Fayalite (USNM 85276); Mn - Spessartine (SPGA). Working standards were analyzed before, during, and after each day within each analytical session, consisting of the following from March 2020: BG2 (USNM 113498/1, VG-A99) and BG3 (USNM 113716).

During the April 2016 analytical session, the analytical beam was set to $15 \mathrm{keV}$ and $10 \mathrm{nA}$, with a 10 micron beam size. Calibration standards used for the April 2016 analytical session are: $\mathrm{Si}, \mathrm{Ti}$, and Fe - BG2 (USNM 113498/1, Al, Mn, Mg, and Ca - VG-A99) BG3 (USNM 113716), Na - CCNM, K - Rhyolite glass (USNM 72854 VG-568), and Cl - Scapolite (USNM R6600-1). Phosphorus was not included in the April 2016 analytical session. The BG3 (USNM 113716) basaltic glass standard was also used as the working standard in the April 2016 session. All working standard data from each analytical session are included in Appendix B. 


\section{ACKNOWLEDGEMENTS}

We thank Maritime Helicopters and pilot Jared Berman and Egli Air Haul and pilot Sam Egli for efficient and safe transportation in the field. We thank Mary Martin and the Cold Bay Lodge staff for comfortable lodging and excellent meals during our fieldwork. Thanks to Ken Severin for making the UAF AIL facility an excellent analytical resource for AVO EPMA analytical work. Max Kaufmann collected ash samples 16PVMK001a and 16PVMK001b analyzed for this study. The AVO tephra analytical routine was created by Matt Loewen (USGS/AVO), Kristi Wallace (USGS/AVO), and Nathan Graham (UAF) and we are grateful for their efforts to standardize the AVO glass EPMA analytical protocols. This material is based upon work supported by the U.S. Geological Survey in a cooperative agreement with the UAF Geophysical Institute and also under Cooperative Agreement No. G19AC00171 to the Alaska Division of Geological and Geophysical Surveys.

\section{REFERENCES}

Johnson, D.M., Hooper, P.R., and Conrey, R.M., 1999, XRF analysis of rocks and minerals for major and trace elements on a single low-dilution $\mathrm{Li}$-tetraborate fused bead: Advances in X-ray Analysis, v. 41, p. 843-867.

Le Bas, M.J., Le Maitre, R.W., Streckeisen, Albert, and Zanetin, B., 1986, IUGS Subcommission on the Systematics of Igneous Rocks, A Chemical Classification of Volcanic Rocks Based on the Total AlkaliSilica Diagram, Journal of Petrology, vol. 27, no. 3, p. 745-750.

https://doi.org/10.1093/petrology/27.3.745

Mangan, Margaret, Miller, T.P., Waythomas, C.F., Trusdell, Frank, Calvert, Andrew, and Layer, P.W., 2009, Diverse lavas from closely spaced volcanoes drawing from a common parent: Emmons Lake Volcanic Center, Eastern Aleutian Arc: Earth and Planetary Science Letters, vol. 287, no. 3-4, p. 363-372. http://doi.org/10.1016/j.epsl.2009.08.018

McNutt, S.R., Miller, T.P., and Taber, J.J., 1991, Geological and seismological evidence of increased explosivity during the 1986 eruptions of Pavlof volcano, Alaska: Bulletin of volcanology, vol. 53, no. 2, p. 86-98.

Miller, T.P., McGimsey, R.G., Richter, D.H., Riehle, J.R., Nye, C.J., Yount, M.E., and Dumoulin, J.A., 1998, Catalog of the historically active volcanoes of Alaska: U.S. Geological Survey Open-File Report 98-0582, $104 \mathrm{p}$.

Nye, C.J., Begét, J.E., Layer, P.W., Mangan, M.T., McConnell, V.S., McGimsey, R.G., Miller, T.P., Moore, R.B., and Stelling, P.L., 2018, Geochemistry of some quaternary lavas from the Aleutian Arc and Mt. Wrangell: Alaska Division of Geological \& Geophysical Surveys Raw Data File 2018-1, 29 p. http://doi.org/10.14509/29843

Waythomas, C.F., Haney, M.M., Fee, David, Schneider, D.J., and Wech, Aaron, 2014, The 2013 eruption of Pavlof Volcano, Alaska: a spatter eruption at an ice-and snow-clad volcano: Bulletin of Volcanology, vol. 76, no. 10, article no. 862. https://doi.org/10.1007/s00445-014-0862-2 
Waythomas, C.F., Haney, M.M., Wallace, K.L., Cameron, C.E., and Schneider, D.J., 2017, The 2014 eruptions of Pavlof Volcano, Alaska: U.S. Geological Survey Scientific Investigations Report 2017-5129, 27 p. https://doi.org/10.3133/sir20175129 


\section{APPENDIX A}

Table A1. Station locations and sample ID. Latitiude and Longitude in NAD83 datum.

\begin{tabular}{|c|c|c|c|c|c|}
\hline Station ID & Latitude & Longitude & Age & Samples collected at location & Abbreviated sample description \\
\hline 17JFLPV001 & 55.45421 & -161.91434 & $2013 ?$ & 17JFLPV001A, 001B & $\begin{array}{l}\text { These samples are from two fresh, fissile, spalling } \\
\text { juvenile bombs. The bombs are dense and poorly } \\
\text { vesicular, containing plagioclase phenocrysts up } \\
\text { to } 2-3 \mathrm{~mm} \text { in size. }\end{array}$ \\
\hline 17JFLPV003 & 55.45886 & -161.95566 & 2016 & 17JFLPV003 & $\begin{array}{l}\text { This sample is from a fresh fissile juvenile bomb } \\
\text { from within a lahar deposit. The lahar deposit } \\
\text { contains sulfur coated blocks, possibly from the } \\
\text { summit crater. }\end{array}$ \\
\hline 17JFLPV010 & 55.37185 & -161.78916 & Holocene & 17JFLPV010 & $\begin{array}{l}\text { This Holocene Pavlof lava flow sample is } \\
\text { phenocryst-rich, and is moss-coated with a thin, } \\
\text { weathered rind and fresh interior. The lava flow } \\
\text { has a sparse covering of alder bushes. }\end{array}$ \\
\hline 17JFLPV011 & 55.3737 & -161.79038 & Holocene & 17JFLPV011A & $\begin{array}{l}\text { Tephra sample from a clean, open-framework } \\
\text { scoria fall deposit. The lapilli are frothy, vesicular } \\
\text { and slightly iridescent. Clasts range in size from } 2 \\
\text { to } 3 \mathrm{~mm} \text { up to } 7 \mathrm{~cm} \text {. The lapilli contain up to } \sim 10 \\
\text { vol. \% phenocrysts. }\end{array}$ \\
\hline 17JFLPV012 & 55.37795 & -161.81252 & Holocene & 17JFLPV012 & $\begin{array}{l}\text { This sample is from a lava flow that is likely } \\
\text { associated with a cinder cone higher up on the SE } \\
\text { flank of Pavlof. The sample has a glassy interior } \\
\text { with } 10 \% \text { or fewer phenocrysts. }\end{array}$ \\
\hline 17JFLPV015 & 55.4526 & -161.93094 & 2016 & $\begin{array}{l}\text { 17JFLPV015A, 17JFLPV015B, } \\
\text { 17JFLPV015C }\end{array}$ & $\begin{array}{l}\text { Three samples of breadcrust bombs from a } 2016 \\
\text { pyroclastic flow deposit mantling the } 2014 \text { lava } \\
\text { flow. The samples contain } 20 \text { to } 30 \% \text { by volume } \\
\text { plagioclase phenocrysts up to } 4 \text { to } 5 \mathrm{~mm} \text { in length, } \\
\text { sparse pyroxene } 3 \text { to } 5 \mathrm{~mm} \text { in length, and rare } \\
\text { olivine } 1 \text { to } 2 \mathrm{~mm} \text { in length. }\end{array}$ \\
\hline 17JFLPV015 & 55.4526 & -161.93094 & 2014 & 17JFLPV015D, 17JFLPV015E & $\begin{array}{l}\text { Two samples from the } 2014 \text { lava flow. Center of } \\
\text { two separate clasts from on top of the flow. } \\
\text { Clastic lava flow. The samples have dark grey } \\
\text { groundmass with } 20 \text { to } 30 \% \text { plagioclase }\end{array}$ \\
\hline
\end{tabular}




\begin{tabular}{|c|c|c|c|c|c|}
\hline Station ID & Latitude & Longitude & Age & Samples collected at location & Abbreviated sample description \\
\hline & & & & & $\begin{array}{l}\text { phenocrysts } \sim 3 \mathrm{~mm} \text { in length, and sparse } \\
\text { pyroxene } 1 \text { to } 2 \mathrm{~mm} \text { in length. }\end{array}$ \\
\hline 17JFLPV016 & 55.45153 & -161.93194 & 2014 & 17JFLPV016A, 016B, 016C & $\begin{array}{l}\text { Sampled dense interiors and carapaces of three } \\
\text { separate, large bomb-sized clasts from the } \\
\text { carapace of the clastogenic } 2014 \text { lava flow. The } \\
\text { clasts have dark grey groundmass, with } 20 \text { to } 30 \% \\
\text { plagioclase phenocrysts that are } 4 \text { to } 5 \mathrm{~mm} \text { in } \\
\text { length. Sparse pyroxene phenocrysts are present, } \\
1 \text { to } 2 \mathrm{~mm} \text { in length. }\end{array}$ \\
\hline 17JFLPV017 & 55.45253 & -161.94825 & 2016 & 17JFLPV017E, 017F, 017G & $\begin{array}{l}\text { Samples from three separate "cauliflower"- } \\
\text { shaped, spalling, prismatic bombs. The bombs } \\
\text { contain } 20 \text { to } 30 \% \text { plagioclase phenocrysts } 3 \text { to } 4 \\
\mathrm{~mm} \text { in length. Sparse pyroxene is present, } \\
\text { typically } 1 \text { to } 3 \mathrm{~mm} \text { in length. Rare olivine is visible } \\
\text { in hand samples, } \sim 1 \mathrm{~mm} \text { in size. }\end{array}$ \\
\hline 17JFLPV017 & 55.45253 & -161.94825 & 2013 & 17JFLPV017A, 017B, 017C, 017D & $\begin{array}{l}\text { Four separate samples from the dense interior of } \\
\text { a } 2013 \text { lava flow. These samples are significantly } \\
\text { different in hand sample petrography than those } \\
\text { from the } 2014 \text { and } 2016 \text { eruption deposits. The } \\
\text { clasts are medium grey in groundmass color. } \\
\text { Pyroxene is more abundant, at } 10 \text { to } 15 \% \text { and } 1 \\
\text { to } 2 \text { to } 3 \mathrm{~mm} \text { in length. Plagioclase is also } \\
\text { abundant, at } 20 \text { to } 25 \% \text {, and is } 3 \text { to } 5 \mathrm{~mm} \text { in } \\
\text { length. }\end{array}$ \\
\hline 17JFLPV018 & 55.48198 & -161.89814 & Holocene & 17JFLPV018A, 018B, 108C, 018D & $\begin{array}{l}\text { Four samples from two different lava flows that } \\
\text { crop out in the same stream channel: } \\
17 J F L P V 018 A \text { represents the dense core of a } \\
\text { lichen and moss covered lava flow. Contains } \\
\text { visible plagioclase and pyroxene phenocrysts in } \\
\text { the hand sample. Samples } 17 J F L P V 018 B, C \text {, and } \\
\text { were collected from three separate clasts } \\
\text { sampled from a clastic lava flow. The samples are } \\
\text { variably red and oxidized and contain plagioclase } \\
\text { phenocrysts. }\end{array}$ \\
\hline 17JFLPV021 & 55.43995 & -161.76135 & Holocene & 17JFLPV021A & $\begin{array}{l}\text { Lava sample from dense core of a Holocene lava } \\
\text { flow of unknown origin. This sample contains }\end{array}$ \\
\hline
\end{tabular}




\begin{tabular}{|c|c|c|c|c|c|}
\hline Station ID & Latitude & Longitude & Age & Samples collected at location & Abbreviated sample description \\
\hline & & & & & $\begin{array}{l}\text { conspicuous pyroxene phenocrysts up to } 5 \mathrm{~mm} \text { in } \\
\text { length, with subordinate plagioclase phenocrysts. } \\
\text { The lava flow is dark grey with a distinct rose- } \\
\text { colored tint and appears older, as it is covered } \\
\text { with lichen and moss. The location creates } \\
\text { ambiguity in the source of this lava flow. It could } \\
\text { be from Pavlof or Pavlof Sister. }\end{array}$ \\
\hline 17JFLPV022 & 55.43184 & -161.75751 & Holocene & 17JFLPV022 & $\begin{array}{l}\text { This sample is from a hackly fractured, micro- } \\
\text { columnar jointed ice-contact lava flow. The } \\
\text { sample is glassy with plagioclase phenocrysts. }\end{array}$ \\
\hline 17JFLPV025 & 55.42349 & -161.78219 & Holocene & 17JFLPV025 & $\begin{array}{l}\text { Previously unsampled Holocene lava flow that } \\
\text { contains } 30-40 \% \text { plagioclase and pyroxene up to } \\
3 \mathrm{~mm} \text { in length, and minor amounts of relict } \\
\text { olivine. The groundmass has a slight rose-colored } \\
\text { tin. }\end{array}$ \\
\hline 17JFLPV026 & 55.40854 & -161.80624 & Holocene & 17JFLPV026 & $\begin{array}{l}\text { Previously unsampled Holocene lava flow that } \\
\text { contains } 30-40 \% \text { plagioclase phenocrysts and } \\
\text { olivine up to } \sim 1 \mathrm{~mm} \text {. This sample does not have } \\
\text { visible pyroxene. }\end{array}$ \\
\hline 17JFLPV031 & 55.42139 & -161.81681 & Holocene & 17JFLPV031 & $\begin{array}{l}\text { Spalling fissile bomb from a recent eruption of } \\
\text { unknown age }\end{array}$ \\
\hline 18JFLPV033 & 55.508 & -161.75411 & Holocene & 18JFLPV033B, 033E, 033G, 033I & $\begin{array}{l}\text { Four samples from a Holocene section containing } \\
\text { coarse lapilli fall deposits. The outcrop is located } \\
\text { to the northeast of Pavlof Sister. 18JFLPV033B } \\
\text { consists of fines poor, clast-supported, well- } \\
\text { sorted lapilli fall from a Holocene eruption. } \\
\text { 18JFLPV033E consists of lower vesicularity scoria } \\
\text { lapilli with clasts up to } 2 \mathrm{~cm} \text { in size. This sample is } \\
\text { predominatly coarse ash to fine lapilli in size, with } \\
5 \mathrm{~mm} \text { to } 1 \mathrm{~cm} \text { clasts. } 18 \mathrm{JFLPVO} 33 \mathrm{G} \text { consists of } \\
\text { higher vesicularity scoria that have a "frittery" } \\
\text { appearance, with the largest clasts to } 17 \text { to } 18\end{array}$ \\
\hline
\end{tabular}




\begin{tabular}{|c|c|c|c|c|c|}
\hline Station ID & Latitude & Longitude & Age & Samples collected at location & Abbreviated sample description \\
\hline & & & & & $\begin{array}{l}\mathrm{mm} \text { in size. These lapilli contain platy, rusty } \\
\text { plagioclase crystals. } 18 \mathrm{JVLPF} 033 \mathrm{I} \text { is similar to } \\
\text { 033G, with vesicular scoria having the "fritter" } \\
\text { texture. The clasts are fine to medium lapilli, up to } \\
2 \mathrm{~cm} \text {, in size. }\end{array}$ \\
\hline 18JFLPV034 & 55.44142 & -161.74325 & Holocene & 18JFLPV034 & $\begin{array}{l}\text { Recent scoria fall deposit mantling the surface. It } \\
\text { is probably mixed eruptions? Representative of } \\
\text { other types of mantling scoria deposits around } \\
\text { the volcano. }\end{array}$ \\
\hline 18JFLPV035 & 55.49128 & -161.71244 & Holocene & 18JFLPV035 & $\begin{array}{l}\text { Recent scoria fall deposit from within a shallow } \\
\text { hole dug by C. Waythomas. The tephra layer } \\
\text { sampled is } 6 \text { to } 7 \mathrm{~cm} \text { beneath the vegetation } \\
\text { surface, and contains fresh scoria large enough } \\
\text { for whole rock analysis ( }>1 \mathrm{~cm} \text { in clast size). }\end{array}$ \\
\hline 18JFLPV037 & 55.54496 & -161.85553 & Holocene & 18JFLPV037I & $\begin{array}{l}\text { Moderately sorted scoria unit that pinches and } \\
\text { swells but is on average } 3-5 \mathrm{~cm} \text { thick. Some scoria } \\
\text { are flattened and ribbon-like being up to } 2.5 \mathrm{~cm} \\
\text { in length although the average clast size is closer } \\
\text { to } 5 \mathrm{~mm} \text {. Free plagioclase crystals are present, } \\
\text { some, which are chalk-white in color, and } \\
\text { approximately } 1 \mathrm{~mm} \text { in size. }\end{array}$ \\
\hline 18JFLPV042 & 55.58615 & -162.01842 & 1996 & 18JFLPV042A, 042B, 042C, 042D & $\begin{array}{l}\text { Four separate large bomb samples collected from } \\
1996 \text { lahar deposit in the Leontovich River valley. } \\
\text { The bombs are possibly juvenile, and are broken } \\
\text { and fractured. Field chipped for clean interior } \\
\text { samples }\end{array}$ \\
\hline 18JFLPV043 & 55.61373 & -162.07076 & 1996 & 18JFLPV043A, 043B, 043C & $\begin{array}{l}\text { Three separate bomb samples from a second } \\
\text { location in the Leontovich River valley. These } \\
\text { bombs appear to be possibly juvenile, and are flat } \\
\text { and spatter-shaped. }\end{array}$ \\
\hline 16PVMК001A & 55.44403 & -161.87825 & 2016 & 16MKPV001A & $\begin{array}{l}\text { 1x1 ft sample. Tephra deposit was } 4.5 \text { inches thick } \\
\text { and overlay winter snow. The deposit was in turn } \\
\text { overlain by more recent spring snows at the edges } \\
\text { of its exposure. The sampled deposit was exposed } \\
\text { at the surface of a glacier by the overlying post- } \\
\text { eruption snow having melted off. Deposit was }\end{array}$ \\
\hline
\end{tabular}




\begin{tabular}{|c|c|c|c|c|c|}
\hline Station ID & Latitude & Longitude & Age & Samples collected at location & Abbreviated sample description \\
\hline & & & & & $\begin{array}{l}\text { more likely tephra fall and not a flow deposit } \\
\text { based on deposit characteristics. }\end{array}$ \\
\hline 16PVMK001B & 55.44403 & -161.87825 & 2016 & 16MKPV001B & $\begin{array}{l}\text { Second sample collected from the same location } \\
\text { as } 16 \text { PVMK001A }\end{array}$ \\
\hline 16PVMК001C & 55.4173 & -161.8937 & 2016 & 16MKPV001C & $<30$ grams powder \\
\hline $\begin{array}{l}\text { AT-3680, 3681, } \\
3682\end{array}$ & 56.00088 & -161.20485 & 2016 & $16 A B V-001,-002,-003$ & $\begin{array}{l}\text { Tephra sample originally collected by Allan } \\
\text { Brandell of Nelson Lagoon and sent to Kristi } \\
\text { Wallace at AVO. Pristine dry (never wetted) } \\
\text { ashfall from March } 28,2016 \text { ashfall in Nelson } \\
\text { Lagoon collected off wood planks of a porch } \\
\text { within hours of the March 28, } 2016 \text { fallout }\end{array}$ \\
\hline АT-2824 & & & 2007 & 07CWPAV-tephra & 2007 ash sample collected near flank of volcano \\
\hline AT-2823 & 55.34 & -160.50 & 1996 & Pav_1996_SP & 1996 ash sample collected at Sand Point, Alaska \\
\hline AT-2822 & 55.03 & -162.63 & 1986 & Pav_1986_CB & 1986 ash sample collected at Cold Bay, Alaska \\
\hline AT-2821 & 55.34 & -160.50 & 2013 & 13KHPAV001-1 & $\begin{array}{l}\text { May 18-19, } 2013 \text { ash sample collected at Sand } \\
\text { Point, Alaska }\end{array}$ \\
\hline
\end{tabular}




\section{APPENDIX B}

EPMA Analytical Conditions

\section{Session: March 2-3, 2020}

\section{JEOL JXA 8530 F electron microprobe microanalyzer}

Working standard published values:

\begin{tabular}{|c|c|c|c|c|c|c|c|c|c|c|c|}
\hline & $\mathrm{SIO2}$ & TIO2 & AL2O3 & FEO & MNO & MGO & CAO & NA2O & $\mathrm{K} 20$ & P2O5 & $\mathrm{CL}$ \\
\hline BASALT GLASS (BG2) & 50.94 & 4.06 & 12.49 & 13.27 & 0.15 & 5.08 & 9.3 & 2.66 & 0.82 & 0.38 & N.A. \\
\hline PUBLISHED VALUES & 51.52 & 1.299 & 15.39 & 9.11 & 0.17 & 8.21 & 11.31 & 2.48 & 0.09 & 0.119 & N.A. \\
\hline
\end{tabular}

\begin{tabular}{|l|l|l|l|l|}
\hline $\begin{array}{l}\text { INTENSITY } \\
\text { CORRECTION }\end{array}$ & $\begin{array}{l}\text { ACCELERATING } \\
\text { VOLTAGE (KV) }\end{array}$ & $\begin{array}{l}\text { BEAM } \\
\text { CURRENT } \\
(\mathrm{NA})\end{array}$ & $\begin{array}{l}\text { BEAM } \\
\text { SIZE } \\
(\mu \mathrm{M})\end{array}$ & WORKING STANDARDS \\
\hline $\begin{array}{l}\text { ZAF } \\
\text { (ARMSTRONG- } \\
\text { LOVE/SCOTT) }\end{array}$ & 15 & 5 & 5 & $\begin{array}{l}\text { BASALTIC GLASS STANDARDS BG1 (USNM 111240/52; VG- } \\
\text { 2); BG2 (USNM 113498/1, VG-A99); BG3 (USNM 113716); }\end{array}$ \\
\hline
\end{tabular}

\begin{tabular}{|l|l|l|l|l|l|l|l|l|}
\hline OXIDE & $\begin{array}{l}\text { PEAK } \\
\text { COUNTIN } \\
\text { G TIME } \\
\text { (S) }\end{array}$ & $\begin{array}{l}\text { LOW } \\
\text { BACKGROU } \\
\text { ND TIME (S) }\end{array}$ & $\begin{array}{l}\text { HIGH } \\
\text { BACKGROU } \\
\text { ND TIME (S) }\end{array}$ & $\begin{array}{l}\text { SPECTROMETER } \\
\#\end{array}$ & $\begin{array}{l}\text { ANALYZING } \\
\text { CRYSTAL }\end{array}$ & $\begin{array}{l}\text { CALIBRATION } \\
\text { STANDARD }\end{array}$ & $\begin{array}{l}\text { ELEMEN } \\
\text { T }\end{array}$ & $\begin{array}{l}\text { AVERAGE } \\
\text { ELEMENTA } \\
\text { L \% ERROR }\end{array}$ \\
\hline $\mathrm{SIO}_{2}$ & & & & 4 & TAP & WOLLASTONITE & SI & 0.3 \\
\hline $\mathrm{TIO}_{2}$ & & & & 3 & PET & RUTILE & TI & 4.6 \\
\hline $\mathrm{AL}_{2} \mathrm{O}_{3}$ & & & & 4 & TAP & CORUNDUM & AL & 0.6 \\
\hline $\mathrm{FEO}$ & & & & 1 & LIF & FAYALITE USNM 85276 & FE & 1.7 \\
\hline $\mathrm{MNO}$ & & & & 1 & LIF & SPESSARTINE SPGA & MN & 18.8 \\
\hline $\mathrm{MGO}$ & & & & 5 & TAP & DIOPSIDE USNM 117733 & MG & 2.6 \\
\hline $\mathrm{CAO}$ & & & & 3 & PET & WOLLASTONITE & CA & 1.5 \\
\hline $\mathrm{NA}_{2} \mathrm{O}$ & & & & 5 & TAP & TALBITE & NA & 2.8 \\
\hline
\end{tabular}




\begin{tabular}{|l|l|l|l|l|l|l|l|l|}
\hline $\mathrm{K}_{2} \mathrm{O}$ & & & & 3 & PET & OR10 & $\mathrm{K}$ & 4.3 \\
\hline $\mathrm{P}_{2} \mathrm{O}_{5}$ & & & & 2 & PET & APAT & $\mathrm{P}$ & 17.9 \\
\hline $\mathrm{CL}$ & & & & 2 & PET & $\begin{array}{l}\text { SCAPOLITE USNM } \\
\text { R6600-1 }\end{array}$ & $\mathrm{CL}$ & 12.9 \\
\hline
\end{tabular}

\section{Working Standard Analyses During Session:}

\begin{tabular}{|c|c|c|c|c|c|c|c|c|c|c|c|c|c|}
\hline $\begin{array}{l}\text { STANDARD } \\
\text { NAME }\end{array}$ & & $\mathbf{N}$ & SIO2 & TIO2 & AL2O3 & FEO & MNO & MGO & CAO & NA2O & K2O & P2O5 & CL \\
\hline \multirow[t]{2}{*}{ BG2-1 } & AVG & $\begin{array}{l}1 \\
0\end{array}$ & 51.7299466 & 4.06682119 & 12.0455539 & 13.3077537 & 0.20820393 & 4.95571007 & 9.29862889 & 2.58343498 & 0.85421797 & 0.39884428 & 0.0255625 \\
\hline & STD DEV & & 0.34580118 & 0.06593425 & 0.13833515 & 0.18208625 & 0.05405205 & 0.05277498 & 0.09933425 & 0.19962527 & 0.05646998 & 0.08438306 & 0.01180691 \\
\hline \multirow[t]{2}{*}{ BG3-1 } & AVG & 5 & 51.8974021 & 1.31545402 & 14.7703384 & 9.08149624 & 0.17633483 & 7.80143636 & 11.4108732 & 2.59351925 & 0.11852488 & 0.12470366 & 0.00773155 \\
\hline & STD DEV & & 0.50471999 & 0.03913181 & 0.19752587 & 0.32728043 & 0.07606433 & 0.27854889 & 0.79389187 & 0.32081401 & 0.03776907 & 0.04536148 & 0.0055322 \\
\hline \multirow[t]{2}{*}{ BG2-2 } & AVG & 5 & 51.2372002 & 4.1041247 & 11.9404971 & 13.3730777 & 0.23120316 & 4.95734807 & 9.28314264 & 2.61828926 & 0.92936388 & 0.35565778 & 0.03067269 \\
\hline & STD DEV & & 0.26753631 & 0.04849217 & 0.0919924 & 0.31502875 & 0.05417849 & 0.05488971 & 0.14967779 & 0.12542814 & 0.07202496 & 0.06711856 & 0.01016994 \\
\hline \multirow[t]{2}{*}{ BG3-2 } & AVG & 5 & 51.8842124 & 1.30076031 & 14.7645837 & 8.83812931 & 0.1823093 & 7.80979984 & 11.5154331 & 2.55050577 & 0.08650759 & 0.10235852 & 0.00575363 \\
\hline & STD DEV & & 0.40606362 & 0.06608999 & 0.27493179 & 0.36674529 & 0.03179907 & 0.76141013 & 0.22038729 & 0.63090827 & 0.0292595 & 0.0467102 & 0.01168084 \\
\hline \multirow[t]{2}{*}{ BG2-3 } & AVG & 5 & 51.2166343 & 4.10297196 & 12.0706411 & 13.3001821 & 0.18846556 & 4.98816016 & 9.14740171 & 2.70487436 & 0.94787579 & 0.41927639 & 0.02270172 \\
\hline & STD DEV & & 0.2758329 & 0.02549036 & 0.23931793 & 0.16281347 & 0.04561251 & 0.0551711 & 0.0322983 & 0.11587811 & 0.06466553 & 0.12600067 & 0.01920041 \\
\hline \multirow[t]{2}{*}{ BG3-3 } & AVG & 5 & 51.2263457 & 1.30498346 & 14.6349824 & 9.09739375 & 0.16479006 & 8.13113323 & 11.1962601 & 2.70874903 & 0.10551436 & 0.130282 & 0.00759832 \\
\hline & STD DEV & & 0.47292314 & 0.02640647 & 0.31164248 & 0.45750872 & 0.04757121 & 0.63087697 & 0.30814191 & 0.66670813 & 0.08139949 & 0.05201055 & 0.01487208 \\
\hline
\end{tabular}




\section{EPMA Analytical Conditions}

\section{Session: April 8-10, 2020}

JEOL JXA 8530F electron microprobe microanalyzer

\begin{tabular}{|l|l|l|l|l|}
\hline INTENSITY CORRECTION & $\begin{array}{l}\text { ACCELERATING } \\
\text { VOLTAGE (KV) }\end{array}$ & $\begin{array}{l}\text { BEAM } \\
\text { CURRENT } \\
(\mathrm{NA})\end{array}$ & $\begin{array}{l}\text { BEAM } \\
\text { SIZE } \\
(\boldsymbol{\mu M})\end{array}$ & WORKING STANDARDS \\
\hline $\begin{array}{l}\text { ZAF (ARMSTRONG- } \\
\text { LOVE/SCOTT) }\end{array}$ & 15 & 10 & 10 & $\begin{array}{l}\text { BASALTIC GLASS (BG-3), USNM } \\
113716\end{array}$ \\
\hline
\end{tabular}

\begin{tabular}{|c|c|c|c|c|c|c|c|c|}
\hline OXIDE & $\begin{array}{l}\text { PEAK } \\
\text { COUNTIN } \\
\text { G TIME } \\
\text { (S) }\end{array}$ & $\begin{array}{c}\text { LOW } \\
\text { BACKGROUN } \\
\text { D TIME (S) }\end{array}$ & $\begin{array}{c}\text { HIGH } \\
\text { BACKGROUN } \\
\text { D TIME (S) }\end{array}$ & $\begin{array}{c}\text { SPECTROMETE } \\
\text { R \# }\end{array}$ & $\begin{array}{l}\text { ANALYZIN } \\
\text { G CRYSTAL }\end{array}$ & $\begin{array}{l}\text { CALIBRATION } \\
\text { STANDARD }\end{array}$ & $\begin{array}{c}\text { ELEMEN } \\
\mathbf{T}\end{array}$ & $\begin{array}{l}\text { AVERAGE } \\
\text { ELEMENTA } \\
\text { L \% ERROR }\end{array}$ \\
\hline $\mathrm{SIO}_{2}$ & 10 & 5 & 5 & 5 & TAPL & $\begin{array}{l}\text { BASALTIC GLASS (BG- } \\
\text { 2), USNM 113498/1 } \\
\text { VG-A99 }\end{array}$ & SI & 0.2 \\
\hline $\mathrm{TIO}_{2}$ & 10 & 5 & 5 & 2 & PETL & $\begin{array}{l}\text { BASALTIC GLASS (BG- } \\
\text { 2), USNM 113498/1 } \\
\text { VG-A99 }\end{array}$ & $\mathrm{TI}$ & 6.1 \\
\hline $\mathrm{AL}_{2} \mathrm{O}_{3}$ & 10 & 5 & 5 & 5 & TAPL & $\begin{array}{l}\text { BASALTIC GLASS (BG- } \\
\text { 3), USNM } 113716\end{array}$ & $A L$ & 0.8 \\
\hline FEO & 10 & 5 & 5 & 1 & LIFL & $\begin{array}{l}\text { BASALTIC GLASS (BG- } \\
\text { 2), USNM 113498/1 } \\
\text { VG-A99 }\end{array}$ & $\mathrm{FE}$ & 3.6 \\
\hline MNO & 15 & 5 & 5 & 1 & LIFL & $\begin{array}{l}\text { BASALTIC GLASS (BG- } \\
\text { 3), USNM } 113716\end{array}$ & MN & 12.7 \\
\hline MGO & 10 & 5 & 5 & 4 & TAPL & $\begin{array}{l}\text { BASALTIC GLASS (BG- } \\
\text { 3), USNM } 113716\end{array}$ & MG & 1.1 \\
\hline CAO & 10 & 5 & 5 & 2 & PETL & $\begin{array}{l}\text { BASALTIC GLASS (BG- } \\
\text { 3), USNM } 113716\end{array}$ & $C A$ & 0.3 \\
\hline $\mathrm{NA}_{2} \mathrm{O}$ & 10 & 5 & 5 & 4 & TAPL & CCNM & NA & 2.6 \\
\hline
\end{tabular}




\begin{tabular}{|l|l|l|l|l|l|l|l|l|l|}
\hline $\mathrm{K}_{2} \mathrm{O}$ & 10 & 5 & 5 & 3 & PETL & $\begin{array}{l}\text { RHYOLITIC GLASS, } \\
\text { USNM 72854 VG-568 }\end{array}$ & K & 3.2 \\
\hline $\mathrm{CL}$ & 10 & 5 & 5 & 3 & PETL & $\begin{array}{l}\text { SCAPOLITE } \\
\text { (MEIONITE), USNM } \\
\text { R6600-1 }\end{array}$ & & $\mathrm{CL}$ & 13.0 \\
\hline
\end{tabular}

Working Standard Analyses During Session:

\begin{tabular}{|l|l|r|r|r|r|r|r|r|r|r|r|r|}
\hline STANDARD NAME & & N ANALYSES & SIO2 & TIO2 & AL2O3 & FEO & MNO & MGO & CAO & NA2O & K2O & P2O5 \\
\hline BG-3 & AVG & 19 & 51.31 & 1.33 & 15.60 & 9.03 & 0.16 & 8.17 & 11.36 & 2.74 & 0.07 & 0.008 \\
\hline & STD DEV & & 0.40 & 0.07 & 0.18 & 0.39 & 0.04 & 0.11 & 0.09 & 0.133 & 0.02 & 0.007 \\
\hline
\end{tabular}

